\title{
GROUNDWATER EVALUATION IN AL-GOFRA OASIS, MIDDLE LIBYA, USING STATISTICAL METHODS
}

\author{
Sameh S. Ahmed \\ Mining and Metallurgical Engineering Department, Faculty of \\ Engineering, Assiut University, Assiut, 71518, EGYPT \\ Email: dr_sameh_mining04@yahoo.com Fax: +20088 2332553

\begin{abstract}
Mohamed Hashem
Civil Engineering Department, Faculty of Engineering, Assiut University, Assiut, 71518, EGYPT
\end{abstract}

(Received August 1, 2006 Accepted August 21, 2006)

\begin{abstract}
With its two main aquifers that feed five villages and serve about 60000 capita, Al-Gofra Oasis, middle Libya, has seldom been subjected thoroughly for water quality evaluation. This paper aims at addressing the current situation of the groundwater at the oasis, studies the sources of pollution to the aquifers and introduces a methodology based on multivariate statistics for better monitoring and regular evaluation of the water quality at that oasis. Multiple Regression Analysis was used to correlate the field water quality data with the laboratory measured chemical parameters. Groundwater is the main/only source of water in that region. The aquifer in Sokna and Wadan is confined and its rocks consist of sand, clay and sandstone. The quality of water in this aquifer is fairly good and the Total Dissolved Solids (TDS) range between 1200 to 1500 ppm. The aquifer in Hun is deep confined aquifer and the quality of water is poor, where the TDS ranges between 4000 and 5000 ppm.
\end{abstract}

KEYWORDS: Water quality; TDS; regression statistics; Al-Gofra oasis

\section{INTRODUCTION}

Nowadays, there is a great concern of the groundwater over the entire world. Some people believe that the next World War will be for the sake of water. In arid areas (like Libya) where groundwater is the main source for developing the county, there is a need for better management and conservation of the available water resources. Despite the lack of adequate treatment of water for drinking dependency on sea desolation, wells and boreholes water are usually used as supplements for the scarce pipe borne-water for drinking with little or no treatment. Industrial growth is swift increasing globally and also is the water demand for industrial processes [1]. The problem has two sides, one is the quantity of the water and the second is the quality of the water. This study investigates the present situation of the groundwater quantity and quality at Al-Gofra oasis, Libya. 


\section{DESCRIPTION OF THE STUDY AREA}

Al-Gofra Oasis is located $270.0 \mathrm{~km}$ south of Surt-Gulf and about 1-3 km north of mountain Al-Harug Al-Aswad. It lies between longitudes $14^{\circ} \mathrm{E}$ and $19^{\circ} \mathrm{E}$ and latitudes $26^{\circ} \mathrm{N}$ and $30^{\circ} \mathrm{N}$ in its eastern part and $28 \mathrm{~N}$ and $30 \mathrm{~N}$ in its western part. It consists of five small villages: Hun, Wadan, Sokna, Al-Fokara, and Zalla (Figure 1). The population is approximately 60,000 capita and distributed over all these villages.

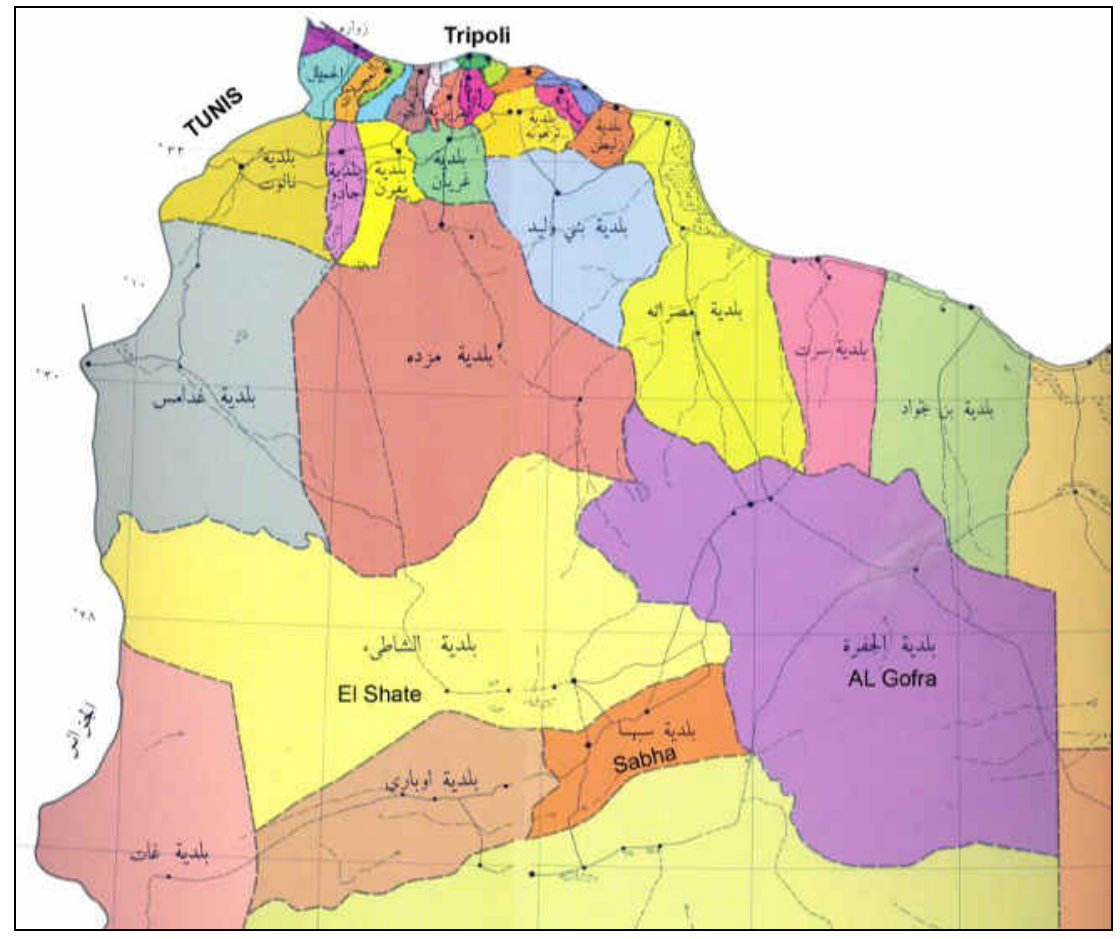

Figure 1: Al-Gofra Oasis, middle Libya.

Climate in this region is typical desert climate. The average temperature in the summer is $44{ }^{\circ} \mathrm{C}$ and in winter it drops to $3^{\circ} \mathrm{C}$ (Figure 2) with a drastic change between day and night.

Relative humidity is very low in summer and reaches $35 \%$ in the winter. Hot wind blows from the south and is considered an active factor in carrying sand particles. Exceptional flooding occurs once every 20-25 years; rainfall is very low with small yearly average value (Figure 3) and occurs in scattered showers from late October until early April.

The general profile of the region has a rough texture and slopes gently south to north, with an average slope along the oasis of $2.0 \mathrm{~m} / \mathrm{km}$. The maximum elevation is about $470 \mathrm{~m}$ above mean sea level (a.m.s.l) in Al-Fokaha and lowest elevation is $200 \mathrm{~m}$ (a.m.s.l) in Zallaa, elevations of Sokna, Hun and Wadan are 300, 260 and 250 (a.m.s.1) respectively. 


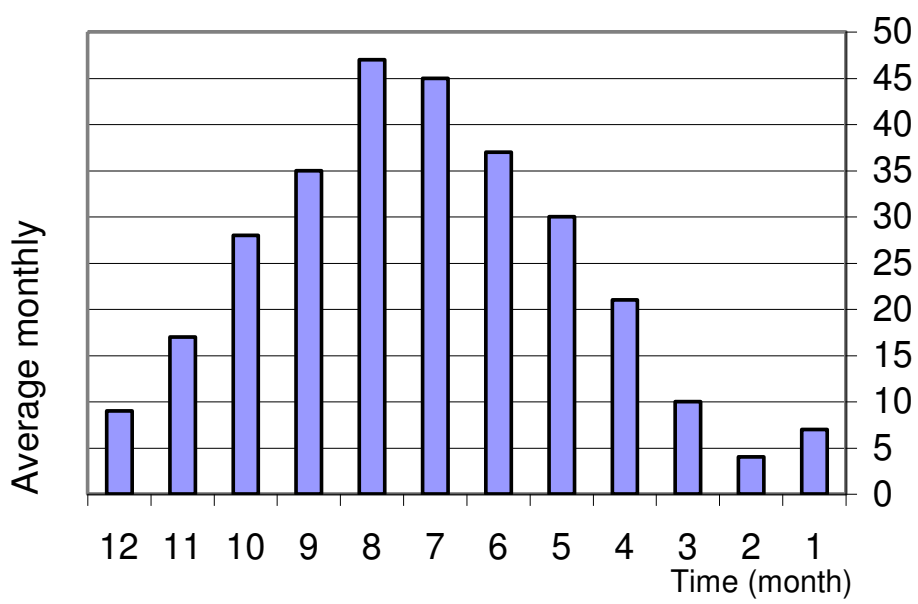

Figure 2: Average monthly temperature $\left({ }^{\circ} \mathrm{C}\right)$.

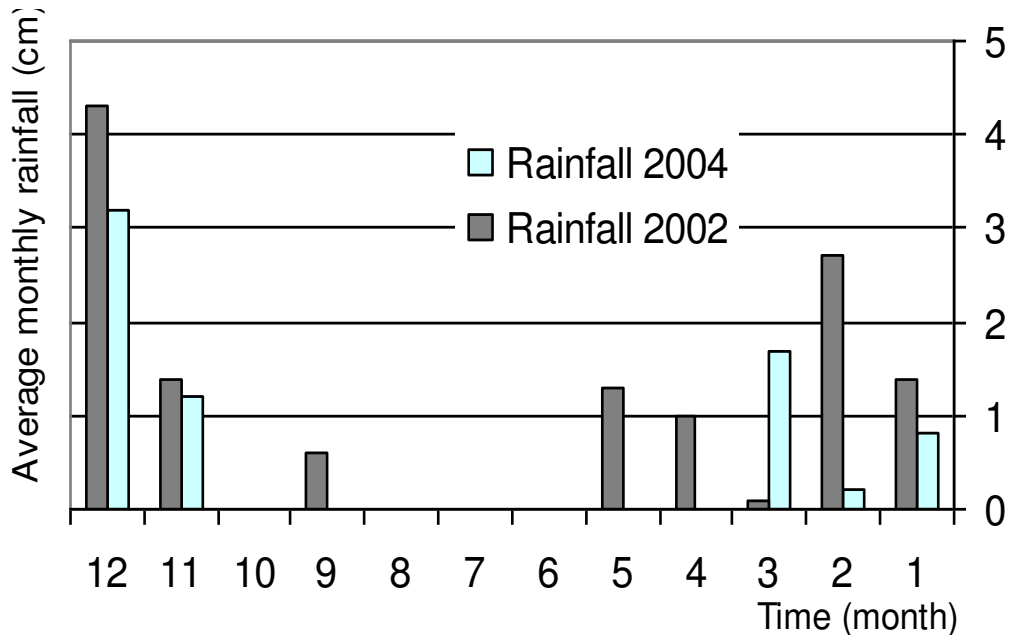

Figure 3: Average monthly rainfall in 2002 and 2004.

\section{GEOLOGY OF AL-GOFRA OASIS}

There have been no detailed studies concerning the structural geology of AlGofra oasis. All the following interpretations are based on well-log information for the wells along the oasis and on surface observations.

The aquifer in Sokna and Wadan is confined and its rocks consist of sand, clay, gypsum and sandstone. The quality of water in this aquifer is good and the Total Dissolved Solids (TDS) ranges between 1200 to $1500 \mathrm{ppm}$. The rock aquifer in Hun is limestone and it is a deep confined aquifer. The quality of water is poor, where the TDS ranges between 4000 and $5000 \mathrm{ppm}$. The aquifer in Zalla is unconfined aquifer and its rocks are sandy rocks. The groundwater level in Zalla aquifer ranges between 30 and $150 \mathrm{~m}$. Also, the aquifer in Al-Fokaha is an unconfined aquifer and its rocks are sandstones. The groundwater level in that aquifer ranges between 40 and $190 \mathrm{~m}$. 
Quality of water in both aquifers (i.e. Zalla and Al-Fokaha) are fairly good, where TDS ranges between 1600 and $2000 \mathrm{ppm}$.

Al-Gofra aquifers are a part of the continental series belonging to the Lower Cretaceous and Upper Jurassic and extend over more than $50 \%$ of Libya. This series is also well developed in Algeria, Egypt and Sudan. These aquifers are considered to be the most important one in dealing with the water resources in Al-Gofra oasis [2]. Figure 4 shows the location of Hun area and the geological formation of the main aquifers from water quality assessment point of view.

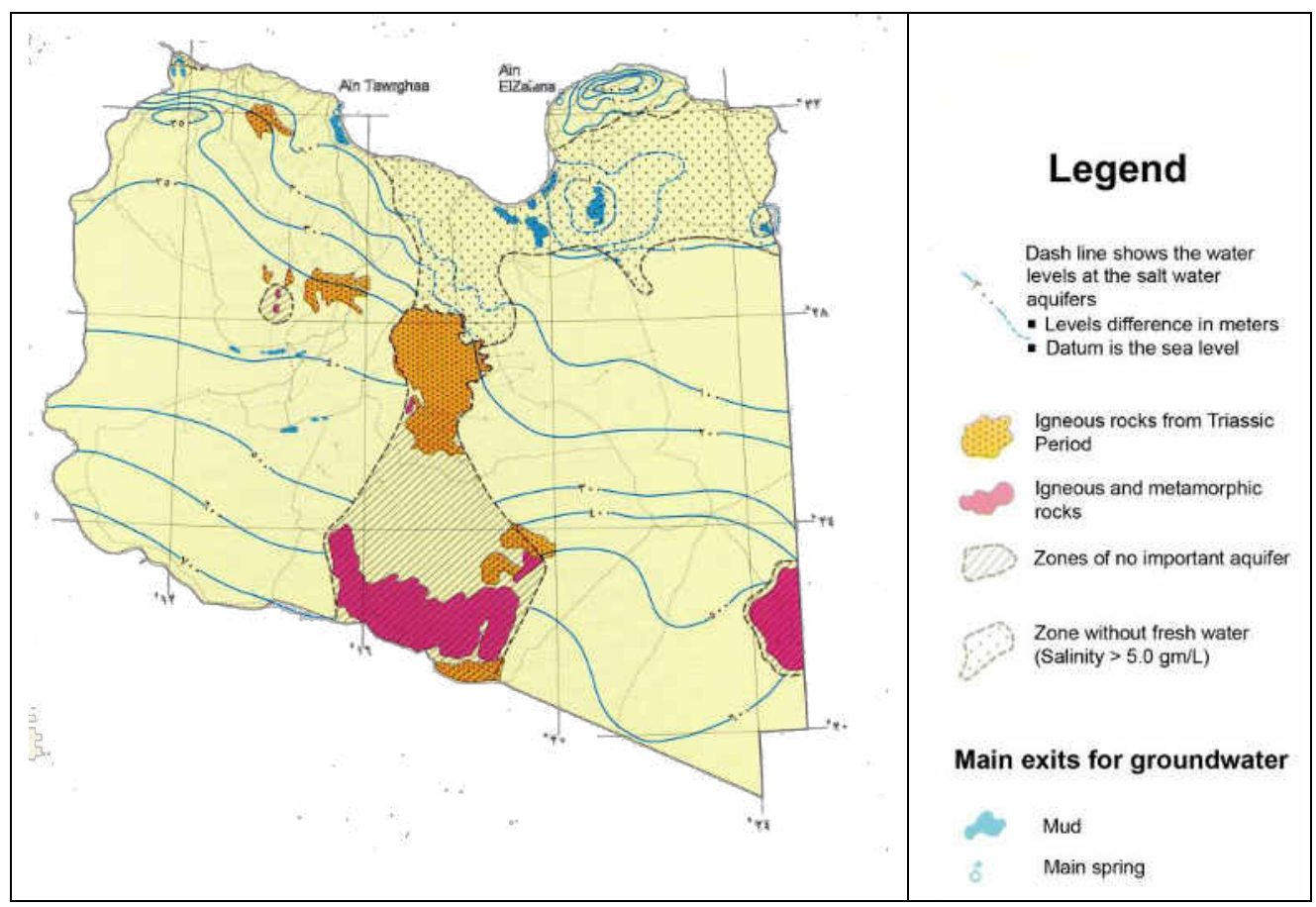

Figure 4: Geological formation and water table levels at the main aquifers of Libya.

\section{WATER CONSUMPTION IN AL-GOFRA}

The only sizeable water resource available in the area is groundwater. This groundwater is used for domestic supply, agriculture and watering animals. Since 1970 hydro-geological investigations have been carried out in an attempt to develop the groundwater and more than 5 deep wells (more than $800 \mathrm{~m}$ ) have been drilled along the oasis, two of them in Zallaa and Al-Fokaha and the rest in Sokna. All these wells are artesian aquifers and have an average yield of about $150.0 \mathrm{l} / \mathrm{s}$.

\section{Discharge and Recharge of Groundwater in Al-Gofra}

Discharge of water from the Al-Gofra aquifers is continuously increasing every year due to increasing water consumption. There is no obvious natural discharge from the aquifers in the study area. About 5 wells have been drilled along the Al-Gofra oasis. The GWA has estimated the amount of irrigation water required per hectare as $9000 \mathrm{~m}^{3} / \mathrm{ha} /$ year. The land call for the development is about 3000 ha. This leads to a 
total water requirement of $27.0 \times 10^{6} \mathrm{~m}^{3} /$ year. The GWA has estimated that the maximum discharge from the aquifers should be $11.0 \times 10^{6} \mathrm{~m}^{3} /$ year. A rough estimate of the hydraulic gradient along the Oasis has been found to be $5 \times 10^{-4}$ towards the north. Therefore, the natural flow was estimated to be $2.2 \times 10^{-1} \mathrm{~m}^{3} / \mathrm{m}^{2} /$ year with transmissivity of $1.8 \times 10^{-2} \mathrm{~m}^{2} / \mathrm{s}$. However, if new information shows this value to be underestimated, it would result in an increase of the water resources available. Consequently, the main part of the water from the deep aquifers in the oasis is coming from storage.

Most of the groundwater in the oasis is either fossilized water or water recharged at great distances from the area. Surface flow is almost absent and occurs occasionally. Water from occasional flood runoff flows slowly along the bed area and results in some recharge to the shallow aquifer as in Al-Fokaha. The shallow groundwater in the area is characterized by perched water bodies along the oasis. These water bodies overlie the regional groundwater. There has been no study on the amount of water recharged to the shallow aquifer.

\section{Storage Coefficient and Transmissivity}

The hydraulic parameters of main aquifer (Wadan-Sokna) have been determined by step-flow and recovery tests carried out on Sokna's wells in 1985 by GWA of Libya [3]. The results are fairly consistent, with transmissivity ranging from $1.6 \times 10^{-2}$ to $2.3 \times 10^{-2} \mathrm{~m}^{2} / \mathrm{s}$ as in Table 1. The storage coefficient (Storativity) was determined only with well-2 flowing and Well-3 as an observation well. The value of storage coefficient was found to be $2 \times 10^{-4}$. The geometric characteristics of this aquifer are rather homogenous and extend over several thousand square kilometers. Therefore, there is no reason to expect important changes of the behavior of this aquifer except over long periods of time or due to new resources (industrial activities).

Table 1: Hydraulic parameters of Wadan-Sokna aquifer [3].

\begin{tabular}{|c|c|c|c|}
\hline Well No. & $\begin{array}{c}\text { Trasnsmissivity }\left(\times 10^{-2}\right) \\
\mathrm{m}^{2} / \mathrm{s}\end{array}$ & Storage coefficient & $\begin{array}{l}\text { Estimated discharge } \\
(1 / \mathrm{s})\end{array}$ \\
\hline 1 & 1.6 & \multirow{5}{*}{$2.1 \times 10^{-4}$} & 41 \\
\hline 2 & 2.3 & & 33 \\
\hline 3 & 2.05 & & 30 \\
\hline 4 & 1.94 & & 166 \\
\hline 5 & 2.1 & & 28 \\
\hline
\end{tabular}

The above values of transmmisivity and storage coefficient were used to calculate the effect of well discharge on the piezometric head. No lateral boundary is expected to affect the long-term behavior of the aquifer, and results based on these parameters can be considered as minimum values that would increase with the contribution from the overlying or underlying strata.

\section{WATER QUALITY AND SOURCES OF POLLUTION}

There are many sources of pollution, which can be concluded as: sewage disposal on land using septic tanks and drains in rural areas. Septic tanks and cesspools 
are the largest of all contributors of wastewater to the ground and are the most frequently reported sources of groundwater contamination over the world [4].

In many areas this sludge, which contains a large number of potential contaminants, is spread on agricultural lands. In some regions liquid sewage that has not been treated or that has undergone partial treatment is sprayed on the land surface. Application of liquid sewage and sewage sludge to the land provides nutrients such as nitrogen, phosphorus, and heavy metals to the soil. One of the potential negative impacts of this type of sewage disposal is degradation of groundwater quality [5]. The second source of pollution is the agriculture activities. Agriculture is probably the most important of all the activities of man that influence the quality of groundwater. Among the main agricultural activities that can cause degradation of groundwater quality are the usages of fertilizers and pesticides and the storage or disposal of livestock or fowl wastes on land. The most widespread effects result from the use of fertilizer. The drain water that can percolate downward to the groundwater table, in the regions of unconfined aquifers, has double or triple of its original TDS. In less developed countries, animal or human wastes are widely used as organic fertilizer but in industrialized countries most fertilizers are manufactured chemically [4].

At Al-Gofra oasis, agriculture activities, nature of soil, waste disposal, over pumping of groundwater and possibility of seawater intrusion are the main potential sources of groundwater pollution at the study area.

\section{ANALYSIS OF DATA AND DISCUSION}

Since all wells tap the same aquifer, chemical analysis was carried out for all five wells in Sokna. Immediate analysis was done in the field to obtain dependable results because the composition of the sample may change before reaching the laboratory. The results of that analysis are shown in Table 2.

Table 2: Field analysis of groundwater in Wadan-Sokna aquifer.

\begin{tabular}{|c|c|c|c|c|c|c|}
\hline $\begin{array}{c}\text { Well } \\
\text { No. }\end{array}$ & $\begin{array}{c}\text { Temp. } \\
\left({ }^{\circ} \mathrm{C}\right)\end{array}$ & $\begin{array}{c}\text { Cond.*10 } \\
\left(25^{\circ} \mathrm{C}\right)\end{array}$ & $\mathrm{pH}$ & $\begin{array}{c}\mathrm{HCO}_{3} \\
(\mathrm{mg} / \mathrm{L})\end{array}$ & $\begin{array}{c}\mathrm{CO}_{2} \\
(\mathrm{mg} / \mathrm{L})\end{array}$ & $\begin{array}{c}\mathrm{H}_{2} \mathrm{~S} \\
(\mathrm{mg} / \mathrm{L})\end{array}$ \\
\hline 1 & 57 & 2.74 & 7.4 & 353 & 68.9 & 0.95 \\
\hline 2 & 55 & 1.61 & 7.1 & 384 & 75.9 & 0.56 \\
\hline 3 & 52 & 1.56 & 6.9 & 360 & 86 & 0.64 \\
\hline 4 & 56 & 1.60 & 7.2 & 390 & 70.9 & 0.72 \\
\hline 5 & 55 & 1.47 & 6.6 & 366 & 83.9 & 0.56 \\
\hline
\end{tabular}

As a general indication of Total Dissolved Solids (TDS), specific conductance values are often useful in a practical manner. For conversion between conductance values and $T D S$, the following relation is used [6].

Where:

$$
\mathrm{TDS}=\mathrm{AC}
$$

$\mathrm{A}=$ conversion factor and its value between 0.55 and 0.75 ;

$\mathrm{C}=$ conductance in microsiemens $(\mu \mathrm{s})$ or micromhos $(\mu \mathrm{mho})$ and

TDS is expressed in $\mathrm{g} / \mathrm{m}^{3}$ or $\mathrm{mg} / \mathrm{L}$. 
Certain chemical analyses were also made in the laboratory from samples collected from the same wells. The results of these analyses are shown in Table 3. They indicate that the water quality for the aquifer is relatively uniform except Well-1. The small variation could be related to the inter-bedded shale layers and/or to experimental error [7]. The chemical analysis of the groundwater indicates that the water is acceptable for the irrigation and domestic usage [8].

Table 3: Chemical constituents of groundwater in main (Wadan-Sokna) aquifer.

\begin{tabular}{|l|c|c|c|c|c|}
\hline $\begin{array}{c}\text { Chemical Parameters } \\
(\mathrm{mg} / \mathrm{L})\end{array}$ & Well 1 & Well 2 & Well 3 & Well 4 & Well 5 \\
\hline $\mathrm{CaCO}_{3}$ & 675 & 510 & 530 & 508 & 545 \\
\hline $\mathrm{Ca}$ & 250 & 142 & 163 & 155 & 160 \\
\hline $\mathrm{Mg}$ & 70.5 & 50 & 48 & 53 & 47 \\
\hline $\mathrm{Na}$ & 280 & 190 & 185 & 193 & 180 \\
\hline $\mathrm{TDS}$ & 1918 & 1127 & 1090 & 1120 & 1030 \\
\hline $\mathrm{TSS}$ & 130 & 101 & 110 & 108 & 99 \\
\hline $\mathrm{TS}$ & 1680 & 1201 & 1200 & 1228 & 1129 \\
\hline $\mathrm{Fe}$ & 22 & 13 & 8 & 11 & 9 \\
\hline $\mathrm{SO}_{4}$ & 515 & 430 & 410 & 390 & 400 \\
\hline
\end{tabular}

Descriptive statistical analysis of the measured data has been used in the primary stage to reveal the mean values of each parameter and highlights the extreme values and ranges (Table 4). Calculations were made using STATGRAPHICS [9].

Table 4: Statistical parameters of the physical and chemical constituents of groundwater in main (Wadan-Sokna) aquifer.

\begin{tabular}{|l|c|c|c|c|c|c|}
\hline \multicolumn{1}{|c|}{$\begin{array}{c}\text { Water quality } \\
\text { parameter }\end{array}$} & Mean & $\begin{array}{c}\text { Standard } \\
\text { Kurtosis }\end{array}$ & $\begin{array}{c}\text { Standard } \\
\text { Skewness }\end{array}$ & Range & Minimum & Maximum \\
\hline $\mathrm{Temp},\left({ }^{\circ} \mathrm{C}\right)$ & 55 & 1.985 & -1.045 & 5 & 52 & 57 \\
\hline $\mathrm{EC} * 10^{3},\left(25^{\circ} \mathrm{C}\right)$ & 1.796 & 2.188 & 1.985 & 1.27 & 1.47 & 2.74 \\
\hline $\mathrm{pH}$ & 7.04 & -0.002 & -0.496 & 0.8 & 6.6 & 7.4 \\
\hline $\mathrm{HCO}_{3}(\mathrm{mg} / \mathrm{L})$ & 370.6 & -1.065 & 0.286 & 37 & 353 & 390 \\
\hline $\mathrm{CO}_{2}(\mathrm{mg} / \mathrm{L})$ & 77.12 & -1.222 & 0.184 & 17.1 & 68.9 & 86 \\
\hline $\mathrm{H}_{2} \mathrm{~S}(\mathrm{mg} / \mathrm{L})$ & 0.686 & 0.816 & 1.288 & 0.39 & 0.56 & 0.95 \\
\hline $\mathrm{CaCO}(\mathrm{mg} / \mathrm{L})$ & 553.6 & 1.846 & 1.806 & 167 & 508 & 675 \\
\hline $\mathrm{Ca}(\mathrm{mg} / \mathrm{L})$ & 174 & 1.996 & 1.860 & 108 & 142 & 250 \\
\hline $\mathrm{Mg}(\mathrm{mg} / \mathrm{L})$ & 53.7 & 1.766 & 1.770 & 23.5 & 47 & 70.5 \\
\hline $\mathrm{Na}(\mathrm{mg} / \mathrm{L})$ & 205.6 & 2.157 & 1.970 & 100 & 180 & 280 \\
\hline $\mathrm{TDS}(\mathrm{mg} / \mathrm{L})$ & 1257 & 2.190 & 1.986 & 888 & 1030 & 1918 \\
\hline $\mathrm{TSS}(\mathrm{mg} / \mathrm{L})$ & 109.6 & 1.116 & 1.361 & 31 & 99 & 130 \\
\hline $\mathrm{TS}(\mathrm{mg} / \mathrm{L})$ & 1287.6 & 2.054 & 1.898 & 551 & 1129 & 1680 \\
\hline $\mathrm{Fe}(\mathrm{mg} / \mathrm{L})$ & 12.6 & 1.258 & 11.483 & 14 & 8 & 22 \\
\hline $\mathrm{SO}{ }_{4}(\mathrm{mg} / \mathrm{L})$ & 429 & 1.505 & 1.630 & 125 & 390 & 515 \\
\hline
\end{tabular}


Table 4 gives a summary statistics for each of the selected data variables. It includes measures of central tendency, and measures of shape. Of particular interest here are the standardized skewness and standardized kurtosis, which can be used to determine whether the sample comes from a normal distribution. Values of these statistics outside the range of -2 to +2 indicate significant departures from normality, which would tend to invalidate many of the statistical procedures normally applied to this data. No variables show standardized skewness values outside the expected range. But, the following variables show standardized kurtosis values outside the expected range: $E C, N a, T D S$ and $T S$. Those variables were transformed for normalization as explained in Table 5.

Table 5: Transformation of some variables for normalization.

\begin{tabular}{|l|l|l|l|}
\hline Variable & Suitable transformation & Standard Kurtosis & Standard Skewness \\
\hline $\mathrm{EC}$ & $1 /(\mathrm{Y})$ & 1.998 & -1.859 \\
\hline $\mathrm{Na}$ & Can not be transformed & & \\
\hline $\mathrm{TDS}$ & $1 /(\mathrm{Y})$ & 2.000 & -1.864 \\
\hline $\mathrm{TS}$ & LOG(Y) & 1.962 & 1.834 \\
\hline
\end{tabular}

Due to the limited number of available data ( 5 wells and each parameter has been recorded once) it has been decided to use Simple Regression and Multiple Regression Analysis methods to determine the relation between the physical water quality parameters (measured in-situ) and the chemical water quality parameters (measured in laboratory). The goal is to minimize the laboratory work by finding a relationship between the two groups. The first group considered here is the field data, and the second being the chemical parameters obtained from the laboratory analysis.

Simple Regression models have been examined considering each of the field parameters as dependent variable and each of the laboratory parameters as independent variable; again the aim is to evaluate the correlation between water quality pairs (field and laboratory). The results of this part showed that $E C$ is correlated strongly with $\mathrm{Ca}$, $\mathrm{Mg}, \mathrm{Na}, \mathrm{SO}_{4}, \mathrm{TDS}, \mathrm{TS}, \mathrm{TSS}$ and $\mathrm{H}_{2} \mathrm{~S}$. No correlation between EC and Temp, $\mathrm{pH}, \mathrm{HCO}_{3}$ and $\mathrm{CO}_{2}$. An example of the obtained results is the output of running $E C$ against $\mathrm{Ca}$, the results of fitting a linear model to describe the relationship between $E C$ and $C a$ is given by the equation below of the fitted model:

$$
\mathrm{EC}=-0.265102+0.0118454 * \mathrm{Ca}
$$

The P-value of the model is $=0.0077$, and since this value in the ANOVA table is less than 0.01 , there is a statistically significant relationship between $E C$ and $\mathrm{Ca}$ at the $99 \%$ confidence level. The R-squared statistic indicates that the model as fitted explains $93.17 \%$ of the variability in $E C$. The correlation coefficient equals 0.9653 , indicating a relatively strong relationship between the variables. The standard error of the estimate shows the standard deviation of the residuals to be 0.16006 . This value can be used to construct prediction limits for new observations.

Figure 5 shows the output results of fitting a multiple linear regression model to describe the relationship between Temp and 2 independent variables. 


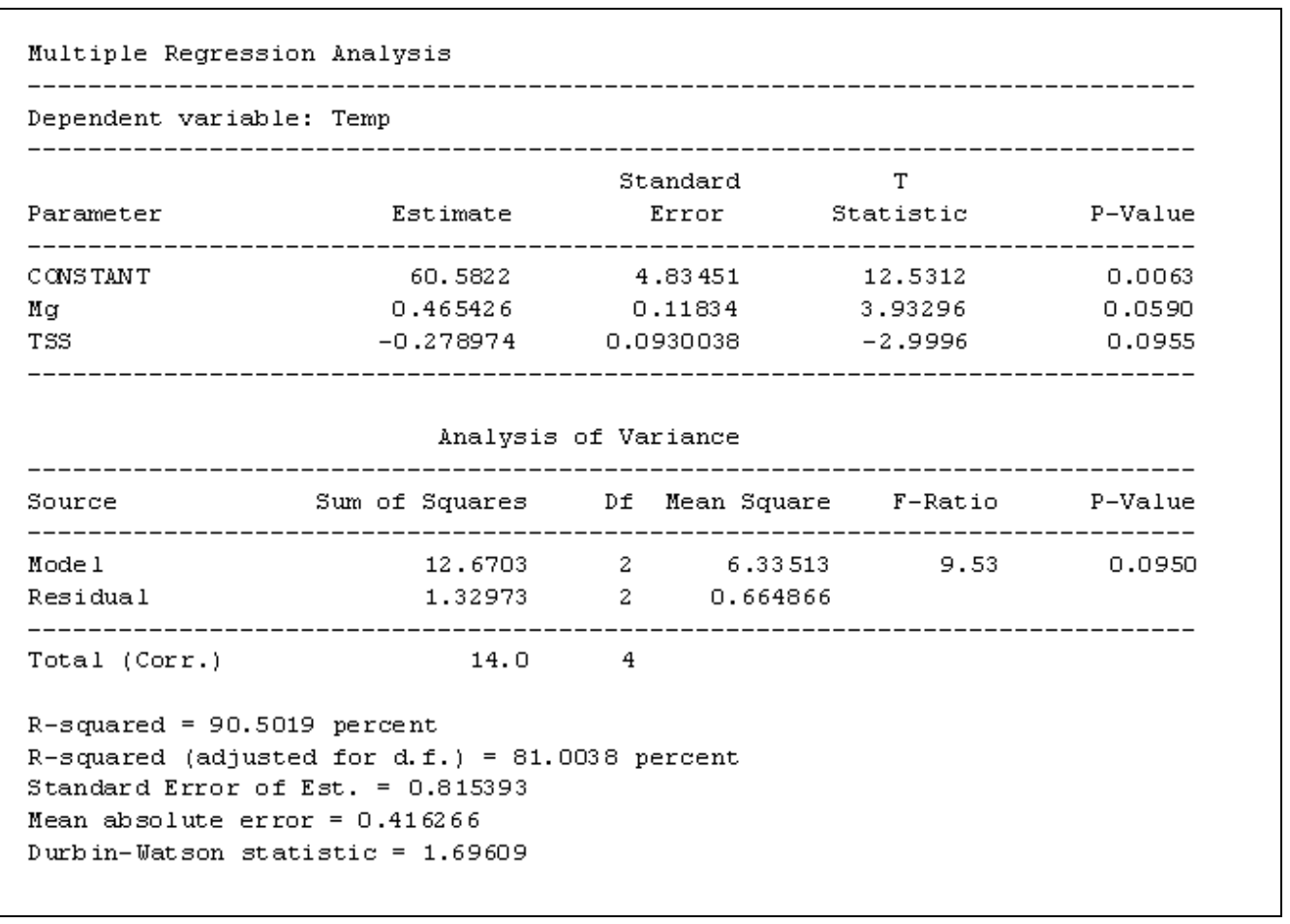

Figure 5: A capture of the results of Multiple Regression Analysis.

The equation of the fitted model is

$$
\mathrm{Temp}=60.5822+0.465426 * \mathrm{Mg}-0.278974 * \mathrm{TSS}
$$

Since the P-value in the ANOVA table is less than 0.10, there is a statistically significant relationship between the variables at the $90 \%$ confidence level. The Rsquared statistic indicates that the model as fitted explains $90.50 \%$ of the variability in Temp. The adjusted R-squared statistic, which is more suitable for comparing models with different numbers of independent variables, is $81.0038 \%$. The standard error of the estimate shows the standard deviation of the residuals to be 0.815393 . This value can be used to construct prediction limits for new observations. The mean absolute error (MAE) of 0.4163 is the average value of the residuals.

Full results of Multiple Regression Analysis are given in the Tables 6 and 7. It should be mentioned that all the possible relations have been examined and only the positive ones are reported here.

Temperature variable is correlated only with the pair $(M g$, TSS). All the other trials to find a suitable model have failed statistically. It might be due to nature of the observed data and the low number of wells. The constants in the provided equations definitely will change as the observations change. But the idea of having a multiple regression model that would help in prediction will still be there. 
Table 6: Multiple regression analysis (one dependent and two independent variables) for the provided data.

\begin{tabular}{|c|c|c|c|}
\hline Variable & Relation with & P-value $>0.1$ & Multiple Regression Equation \\
\hline Temp & Mg, TSS & 0.0950 & $\begin{array}{c}\text { Temp }=60.5822+0.465426 * \mathrm{Mg}- \\
0.278974 * \mathrm{TSS}\end{array}$ \\
\hline \multirow{13}{*}{ EC } & $\mathrm{CaCO}_{3}, \mathrm{Mg}$ & 0.0099 & $\begin{array}{c}\mathrm{EC}=-1.61221+0.00245698 * \mathrm{CaCO}_{3}+ \\
0.0381382 * \mathrm{Mg}\end{array}$ \\
\hline & $\mathrm{CaCO}_{3}, \mathrm{Ca}$ & 0.0677 & $\begin{array}{c}\mathrm{EC}=0.0368217-0.0010882 * \mathrm{CaCO}_{3}+ \\
0.0135724 * \mathrm{Ca}\end{array}$ \\
\hline & $\mathrm{CaCO}_{3}, \mathrm{TSS}$ & 0.0506 & $\begin{array}{c}\mathrm{EC}=-2.68445+0.00411285 * \mathrm{CaCO}_{3}+ \\
0.0201057 * \mathrm{TSS}\end{array}$ \\
\hline & $\mathrm{CaCO}_{3}, \mathrm{SO}_{4}$ & 0.0495 & $\begin{array}{c}\mathrm{EC}=-2.57782+0.00320635 * \mathrm{CaCO}_{3}+ \\
0.00605778 * \mathrm{SO}_{4}\end{array}$ \\
\hline & $\mathrm{Ca}, \mathrm{Mg}$ & 0.0143 & $\begin{array}{c}\mathrm{EC}=-0.891102+0.036216 * \mathrm{Mg}+ \\
0.00426611 * \mathrm{Ca}\end{array}$ \\
\hline & $\mathrm{Ca}, \mathrm{Fe}$ & 0.0062 & $\begin{array}{c}\mathrm{EC}=0.0498091+0.0464302 * \mathrm{Fe}+ \\
0.00667339 * \mathrm{Ca}\end{array}$ \\
\hline & $\mathrm{Ca}, \mathrm{SO}_{4}$ & 0.0253 & $\begin{array}{c}\mathrm{EC}=-1.51984+0.00509826 * \mathrm{SO}_{4}+ \\
0.00648671 * \mathrm{Ca}\end{array}$ \\
\hline & $\mathrm{Ca}, \mathrm{TSS}$ & 0.0593 & $\begin{array}{c}\mathrm{EC}=-1.01971+0.0119659 * \mathrm{TSS}+ \\
0.00864512 * \mathrm{Ca}\end{array}$ \\
\hline & $\mathrm{Mg}, \mathrm{TSS}$ & 0.0264 & $\begin{array}{c}\mathrm{EC}=-1.40568+0.0463411 * \mathrm{Mg}+ \\
0.00650694 * \mathrm{TSS}\end{array}$ \\
\hline & $\mathrm{Fe}, \mathrm{TSS}$ & 0.0129 & $\begin{array}{c}\mathrm{EC}=-1.09991+0.0201931 * \mathrm{TSS}+ \\
0.0541863^{*} \mathrm{Fe}\end{array}$ \\
\hline & $\mathrm{SO}_{4}, \mathrm{TSS}$ & 0.0231 & $\begin{array}{c}\mathrm{EC}=-2.93809+0.0190517 * \mathrm{TSS}+ \\
0.00616788 * \mathrm{SO}_{4}\end{array}$ \\
\hline & $\mathrm{Mg}, \mathrm{Fe}$ & 0.0278 & $\begin{array}{c}\mathrm{EC}=-0.874503+0.0465579 * \mathrm{Mg}+ \\
0.0135192 * \mathrm{Fe}\end{array}$ \\
\hline & $\mathrm{Fe}, \mathrm{SO}_{4}$ & 0.0533 & $\begin{array}{c}\mathrm{EC}=-1.12141+0.00550567 * \mathrm{SO}_{4}+ \\
0.0440852 * \mathrm{Fe}\end{array}$ \\
\hline \multirow{2}{*}{$\mathrm{pH}$} & $\mathrm{CaCO}_{3}, \mathrm{Mg}$ & 0.0446 & $\begin{array}{c}\mathrm{pH}=6.84308-0.00566218 * \mathrm{CaCO}_{3}+ \\
0.0620391 * \mathrm{Mg}\end{array}$ \\
\hline & $\mathrm{Ca}, \mathrm{Mg}$ & 0.0940 & $\begin{array}{c}\mathrm{pH}=5.15904-0.0102688 * \mathrm{Ca}+ \\
0.0683002 * \mathrm{Mg}\end{array}$ \\
\hline
\end{tabular}

On the other hand, Multivariate statistics methods, Principal Component Analysis (PCA) and Factor Analysis (FA) could be applied only when the number of observations is not less than 30 [10].

Figure 6 shows the classification of the Libyan aquifers according to the salinity of the water. 
Table 7: Multiple regression analysis (one dependent and three independent variables) for the provided data.

\begin{tabular}{|c|c|c|c|}
\hline Variable & Relation with & P-value $>0.1$ & Multiple Regression Equation \\
\hline Temp & $\mathrm{Mg}$, TSS, Fe & 0.066 & $\begin{array}{c}\text { Temp }=57.662+0.934848 * \mathrm{Mg}- \\
0.41994 * \mathrm{TSS}-0.542687 * \mathrm{Fe}\end{array}$ \\
\hline \multirow{4}{*}{ EC } & $\begin{array}{l}\mathrm{CaCO}_{3}, \mathrm{SO}_{4}, \\
\mathrm{Mg}\end{array}$ & 0.0455 & $\begin{array}{c}\mathrm{EC}=-1.88512+0.0317285 * \mathrm{Mg}+ \\
0.0013702 * \mathrm{CaCO}_{3}+0.00284095 * \mathrm{SO}_{4}\end{array}$ \\
\hline & $\mathrm{CaCO}_{3}, \mathrm{TSS}, \mathrm{Fe}$ & 0.0171 & $\begin{array}{c}\mathrm{EC}=-1.42673+0.043404 * \mathrm{Fe}+ \\
0.00207232 * \mathrm{CaCO}_{3}+0.013947 * \mathrm{TSS}\end{array}$ \\
\hline & $\mathrm{Ca}, \mathrm{Mg}, \mathrm{SO}_{4}$ & 0.0186 & $\begin{array}{l}\mathrm{EC}=-1.53606+0.00270737 * \mathrm{Ca}+ \\
0.0273887 * \mathrm{Mg}+0.00324058 * \mathrm{SO}_{4}\end{array}$ \\
\hline & $\mathrm{Mg}, \mathrm{TSS}, \mathrm{SO}_{4}$ & 0.0655 & $\begin{array}{c}\mathrm{EC}=-2.08564+0.0278812 * \mathrm{Mg}+ \\
0.00637869 * \mathrm{TSS}+0.00392848 * \mathrm{SO}_{4}\end{array}$ \\
\hline
\end{tabular}

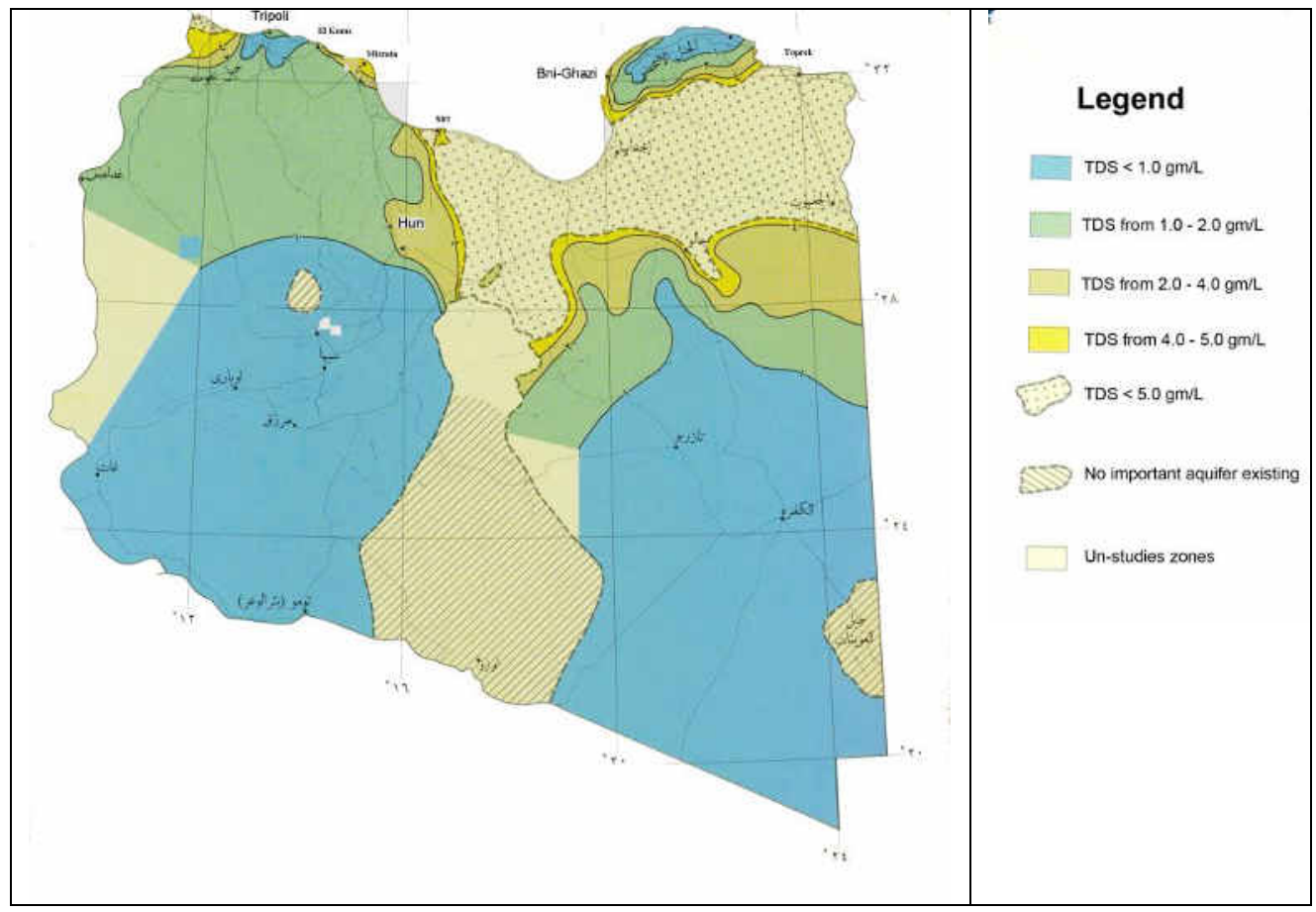

Figure 6: Classification of the Libyan aquifers according to their water quality.

\section{CONCLUSIONS AND RECOMMENDATIONS}

In this paper, water resources in Al-Gofra Oasis have been evaluated. The main source of water in that region is the groundwater. Despite the fact that one of the two aquifers (Wadan - Sokna) is fairly good (TDS: $1200-1500 \mathrm{ppm}$ ) the other one (Hun) has high (TDS: 4000 - $5000 \mathrm{ppm}$ ) which needs special water treatment to cure the 
different $T D S$. The approach introduced in this paper would assist the frequent monitoring of the different water quality parameters and will encourage the authorities to get early warning of any contaminant that might affect the main sources of groundwater. The regression statistics methods over the provided data showed that there is a strong relationship between $E C$ and most of the chemical parameters. Measuring some physical parameters such as Temp, $p H$ and $E C$ and using some indicators appropriate regression equation will assist in predicting the possible values of the other chemical parameters. This will save time and costs in the monitoring program. Not to mention, the values of the calculated regression coefficients in the above work are subjected to the availability of the data, the more the data the better the prediction of the strong correlation.

Water resources development in Al-Gofra can be developed and used in many different ways. However, the following should be considered:

- Construct a water treatment plant for groundwater in Hun and Wadan, where TDS is very high and water can not be used for domestic or agriculture without treatment.

- Use the recycle water from wastewater treatment plants for agriculture.

- Use the Geographic Information System (GIS) and Remote Sensing techniques to develop hydrological maps for water resources in that region and observing the change of water amount and its direction of movement.

- Develop the irrigation methods to optimize the amount of water used in irrigation.

\section{ACKNOLEDGEMENT}

The authors would like to thank the Groundwater Authority at Hun, Libya for their cooperation and providing the data used throughout this work.

\section{REFERENCES}

[1] Fakayode, O.S. (2005): "Impact of assessment of industrial effluent on water quality of the receiving Alaro river in Ibadan, Nigeria", AJEAM-RAGEE, (vol. 10), p1-13.

[2] Jarroud, O.A. (1978): "Groundwater evaluation in Wadi Zamzam, NW Libya", Geology of Libya Conference, Tripoli, Libya.

[3] General Water Authority (GWA) (1985): "Groundwater in Hun Graben", Tripoli, Libya.

[4] Freeze, R.A. and Cherry, J.A. (1979): “Groundwater”, Prentice-Hall, Inc., NJ.

[5] Fried, J.J. (1976): "Ground water pollution", Elsevier, Amsterdam.

[6] Hem, J.D. (1970): "Study and interpretation of the chemical characteristics of natural water”, U.S. Geol. Surv., Water Supply Paper, 1473, pp. 363.

[7] Zarazzer, D. (1985): "Groundwater quality in the central region of the Libyan Arab Republic", Unpublished Report, General Water Authority, (GWA), Tripoli, Libya.

[8] Israelson, O.W. and Hansen, V.E. (1962): "Irrigation principles and practices", John Wiley, New York. 
[9] STATGRAPHICS Plus, (1996): Statistical graphics Corp.

[10] Tabachnick, B.G., and Fidell, L.S. (2001): "Using multivariate statistics", Allyn $\&$ Bacon, London $4^{\text {th }}$ ed.

\section{تقييم المياه الجوفيّة في واحة الجفرة - وسط ليبيا باستخدام الطرق الإحصائية}

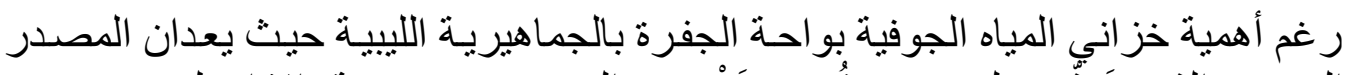

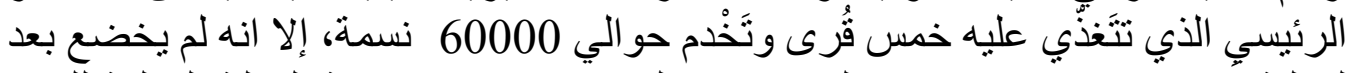

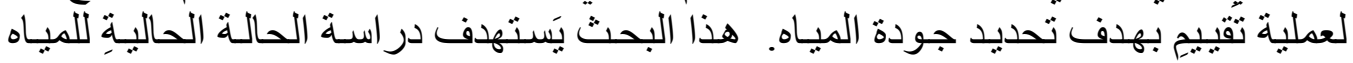

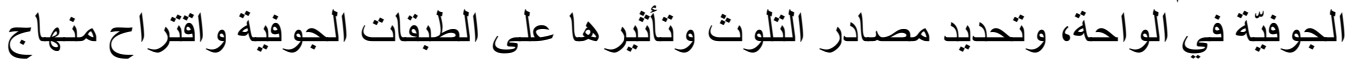

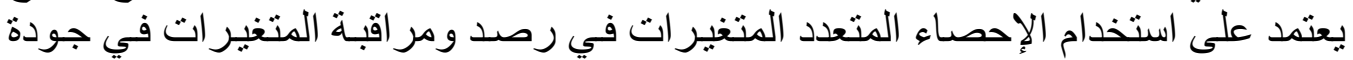

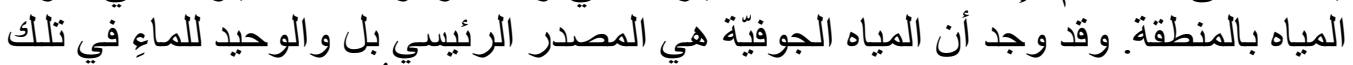

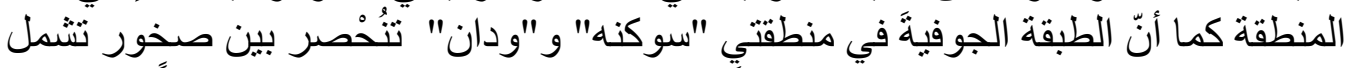

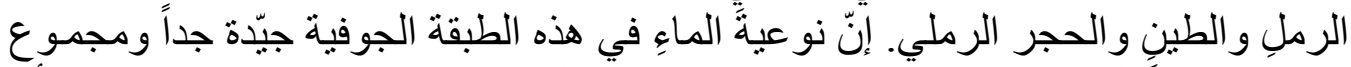

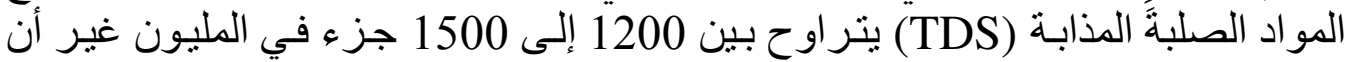

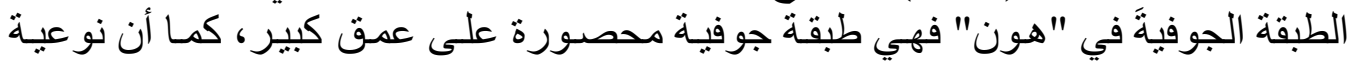

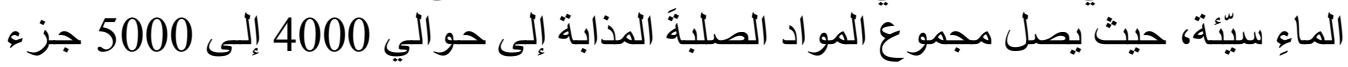
في المليون. 